\title{
SOME MORE TRANSLATION HEADACHES IN ROMANS
}

Author:

Andrie B. du Toit ${ }^{1}$

\section{Affiliation:}

${ }^{1}$ Department of New

Testament, University of

Pretoria

\section{Correspondence to:}

Andrie du Toit

email:

andriedt@icon.co.za

Postal address:

PO Box 92345, Mooikloof,

Pretoria 0059, South Africa

\section{Keywords:}

Bible translations;

charismata; commentaries;

etymological fallacy; gentiles; translation

equivalents; witnessing

\section{Dates:}

Received: 06 Apr. 2010

Accepted: 08 June 2010

Published: 21 Sept. 2010

How to cite this article:

Du Toit, A.B., 2010, 'Some more translation headaches in Romans', Verbum et

Ecclesia 31(1), Art. \#385,

5 pages. DOI: $10.4102 /$

ve.v31i1.385

This article is available

at:

http://www.ve.org.za (c) 2010. The Authors.

Licensee: OpenJournals

Publishing. This work

is licensed under the

Creative Commons

Attribution License.

\section{ABSTRACT}

Following on a previous article, three more problematic lexical items which occur repeatedly in

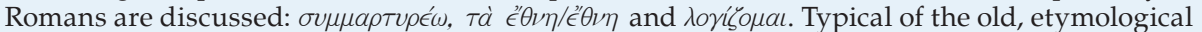
approach, translators are often inclined to attach too much weight to the preposition oú in

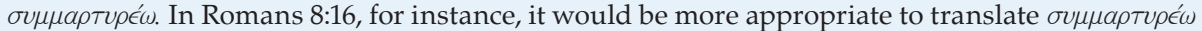
in the sense of 'affirm': ' $t$ the Spirit of God affirms to our spirit that we are God's children'. Despite all objections, rendering $\tau \dot{\alpha}$ '́ $\theta \nu \eta$ as 'Gentiles/Gentile nations' still remains the best option. In certain contexts in Romans, it would be advisable to translate toyíopa as 'I realise/ am convinced'. Thereafter some ad hoc problems in Romans 12:6-8; 14:4 and 15:17 are discussed.

\section{INTRODUCTORY REMARKS}

In a previous article (Du Toit 2010a), I discussed a number of recurring lexical items in Romans that pose problems to the translator. In this article, I shall focus on three other terms in the same category,

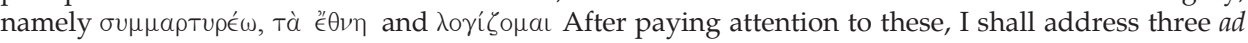
hoc translation problems in Romans.

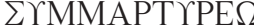

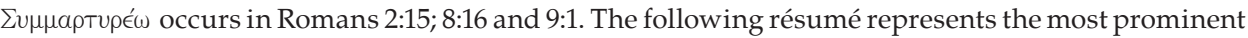
positions taken by translators (italics added):

\section{Romans 2:15}

RSV52': 'while their conscience also bears witness'

NIV84: $\quad$ 'their conscience also bearing witness'

Lut84: 'zumal ihr Gewissen es ihnen bezeugt'

NAB86: $\quad$ 'while their conscience also bears witness'

NRSV89: 'to which their conscience also bears witness'

REB89: $\quad$ 'to this their conscience gives supporting witness'

GNT92: $\quad$ 'Their consciences also show that this is true'

NBV04: $\quad$ 'en hun geweten bevestigt dit'

\section{Romans 8:16}

RSV52: $\quad$ 'it is the Spirit himself bearing witness with our spirit that we are children of God'

NIV84: $\quad$ 'The Spirit himself testifies with our spirit that we are God's children'

Lut84: $\quad$ 'Der Geist selbst gibt Zeugnis unserm Geist'

NAB86: $\quad$ 'The Spirit itself bears witness with our spirit that we are children of God'

NRSV89: $\quad$ 'it is that very Spirit bearing witness with our spirit that we are children of God'

REB89: $\quad$ 'The Spirit of God affirms to our Spirit that we are God's children'

GNT92: $\quad$ 'God's Spirit joins himself to our spirit to declare that we are God's children'

NBV04: $\quad$ 'De Geest zelf verzekert onze geest dat wij Gods kinderen zijn'

\section{Romans 9:1}

RSV52: $\quad$ 'my conscience bears me witness in the Holy Spirit'

NIV84: 'my conscience confirms it in the Holy Spirit'

Lut84: 'wie mir mein Gewissen bezeugt im heiligen Geist'

NAB86: $\quad$ 'my conscience joins with the holy Spirit in bearing me witness'

NRSV89: 'my conscience confirms it by the Holy Spirit'

REB89: $\quad$ 'my conscience, enlightened by the Holy Spirit, assures me'

GNT92: $\quad$ 'My conscience, ruled by the Holy Spirit, also assures me'

NBV04: 'en mijn geweten, geleid door de heilige Geest, is mijn getuige'

I shall start with Romans 8:16, not only because this verse is theologically so important but also since the main translation tendencies are most apparent here. Typical of the old, etymological approach to

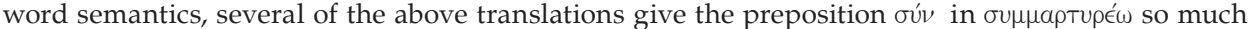
weight that it is rendered by 'bearing witness with' (cf. particularly RSV52, NIV84, NAB86, NRSV89). ${ }^{2}$ Thus we end with two witnesses: the Spirit as well as our own spirit. ${ }^{3}$

1.For the details of the Bible translations quoted above and their abbreviation, see the Reference list.

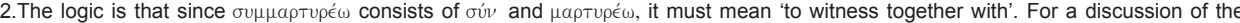
etymological fallacy, see Herman du Toit (2009:295-298). He demonstrates that, while the meaning of compound words sometimes may coincide with the meanings of their constituent parts, this is often not the case.

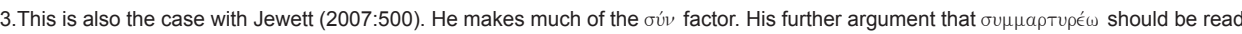
together with the oúv compounds in the last part of $8: 17$ is quite far-fetched. 
Significantly, Louw and Nida (1988 (1):418-419; 2:232) do not even mention 'to give witness (together) with' as a potential meaning

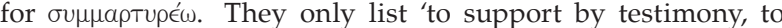
provide supporting evidence, to testify in support'. BAGD (2000: s.v.) mentions a few examples of 'to bear witness with', but the majority of their material supports the meanings 'confirm' or 'testify in support'. Notably, they remark in this regard: 'the prefix ouv- has in the highest degree the effect of strengthening (which would mean 'to confirm', 'to testify in support'). We can aptly illustrate this 'strengthening' function of oúv in the

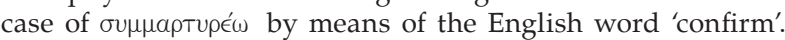
Although 'confirm' originally derives from the Latin con (which again goes back to cum) plus fero, no one would currently assign a 'together with' significance to 'con' in the verb 'confirm'. It rather has an emphatic or strengthening function.

In contrast to the four translations mentioned above, The Revised English Bible (1989) reads: '[t]he Spirit of God affirms to our spirit that we are God's children' (cf. also GNB97; NBV04). ${ }^{4}$ In my opinion, this is a better translation and one agreeing with the bulk of evidence ${ }^{5}$ for the predominant meaning of

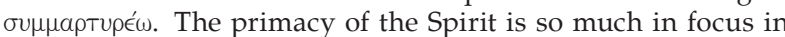
Romans 8 that it is difficult to imagine that Paul would present our spirit as a witness together with the Spirit of God (see also Cranfield 1977:403). The function of the Spirit is much rather to give our spirit the assurance that we are God's children. The Dutch Nieuwe Bijbelvertaling (2004) reflects this succinctly: 'De Geest zelf verzekert onze geest dat wij Gods kinderen zijn.

Going back to 2:15: once again the influence of the etymological approach is evident. The majority of translators, looking for a secondary witness alongside the conscience, but realising the difficulty of finding such a witness, ${ }^{6}$ sidetracked the problem by simply inserting an 'also' after 'conscience', e.g. 'their conscience also bears witness' (RSV52, NAB86, NRSV89; cf. NIV84). The readers are left with the unenviable task of figuring out the identity of the other witness. The problem is

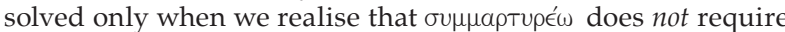
a secondary witness, but should be understood in the sense of testifying, affirming. ${ }^{7}$ Here again, the Nieuwe Bijbelvertaling (2004) is in the right (cf. Lut84). Basically, Romans 2:14-15 states that when non-Jews carry out the precepts of the Law, they show that what the Law requires is inscribed in their hearts and that their conscience affirms the validity of this proposition. Man's conscience is understood as an inner monitor which can pronounce impartial judgments on his behaviour, thus independently affirming or denouncing it. ${ }^{8}$

In 9:1, as attested by the translations cited above, the etymological ghost seems to have been put to rest. The only exceptions are The New American Bible (1986) and, to some degree, The Good News

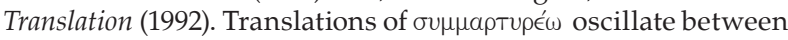
'witnessing/giving evidence', 'confirming' and 'assuring'. Paul wants to convince his readers/auditors of the sincerity of his sorrow on behalf of his people and calls on his conscience, as the objective inner monitor of his feelings and actions, to authenticate that his grief is real. The bearing of the dative

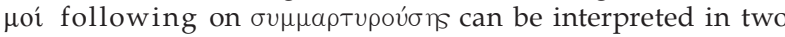
directions: (1) functioning as an indirect dative, it may indicate that the affirmation is given to Paul. Most translations seem to understand $\mu \circ$ in this sense. However, within the rhetorical situation of Romans 9:1ff, it seems highly unlikely that Paul would leave the door even so slightly open for a suspicion that he personally needed some reassurance; (2) it seems much more

4.The GNT92 (quoted above) unconvincingly tries to conflate both positions

5.Vide supra.

6.On the conundrum of finding such a secondary witness, see Cranfield (1977:160 162); Bosman (2003:249-250).

7.Cf. already Cranfield (1977:160-161, 162).

8.See Bosman (2003:191-275 and particularly 264-275, for Paul's view of conscience. likely that $\mu$ oi should be understood as a datious commodi: Paul's conscience, as an independent and objective witness, affirms towards his readers/audience on behalf of Paul that his sorrow and pain are genuine. If this understanding is correct, Romans 9:1-2 could be translated as follows: 'I am speaking the truth in Christ, ${ }^{9}$ I am not lying; my conscience, guided by the Holy Spirit, bears witness on my behalf that there is great sorrow and unceasing anguish in my heart.'

\section{TA EONH}

Translating $\tau \grave{\alpha} ~^{\prime \prime} \theta \nu \eta / \epsilon^{\prime \prime} \theta \nu \eta$ presents us with a problem of a different kind. Since 'Gentiles' as a translation equivalent for $\tau \grave{\alpha} \epsilon^{\prime \prime} \theta \nu \eta$ is experienced by some as derogatory, the question is whether it should not be avoided. Jewett, for instance, openly declares that this term is prejudicial (2007:111)..$^{10}$ Dabelstein in turn, proposes that $\epsilon^{\prime \prime} \theta \nu \eta$ should not be rendered as 'Heiden', since it is derogatory, but by 'non-Jews', 'nations' ('Völker') or, occasionally, as 'the world of nations' ('Völkerwelt') (1981:37). Only in those cases where Paul himself clearly refers negatively to the $\epsilon^{\prime \prime} \theta v \eta$, such as when he associates them with idolatry or moral depravity (e.g. Rm 2:24; 1 Cor 5:1; 12:2; Gl 2:15; 1 Th

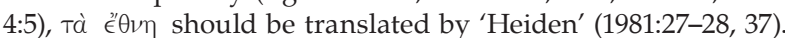
Appealing to the influence of the table of nations tradition on Paul, Scott (1995: esp. 121-134) is also of the opinion that Tò $\epsilon^{\prime \prime} \theta \nu \eta$ should rather be rendered as 'the nations.'11 Concerning Dabelstein's position, it should be observed that the German word 'Heide' may be experienced as more deprecatory than the English word 'Gentile', since in the former, the notion of being a non-believer/pagan/heathen is in primary focus, while in the case of 'Gentile' this is not necessarily the case. ${ }^{12}$ It is understandable, therefore, that German and linguistically related translations may be more inclined to find alternatives than English ones. ${ }^{13}$

But let us look more closely at Romans. In Romans 4:17-18, $\pi \circ \lambda \lambda \omega \hat{\epsilon} \dot{\epsilon} \theta \nu \omega \nu$ is used twice inclusively, embracing Jews as well as non-Jews. ${ }^{14}$ Therefore, 'all nations' is an appropriate translation. The problem lies with the remaining occurrences, where Bible translations predominantly use the term 'Gentiles': Romans 1:5,13; 2:14, 24; 3:29 (bis); 9:24,30; 11:11,12,13 (bis), 25; 15:912 (6 occurrences), ${ }^{15} 16$ (bis), 18,$27 ; 16: 4,[26]$.

Before addressing this problem, some preliminary observations are necessary. The methodological issue comes first: the basic principle in Bible translations worldwide is that the sense of the source text should be communicated as accurately as possible. That sense should be determined by linguistic means, which naturally includes contextual, cultural and socio-historical insights. Apologetic considerations should not be allowed to water it down, even if the text contains derogatory or even vituperative elements. Apologetics has its place, but certainly not at the translational stage. Secondly, we should keep in mind that in the Bible we deal with religious texts. Religious

9.Some translations, on good grounds, prefer to render 'év X $\rho\llcorner\sigma T \hat{\varphi}$ by 'as a Christian' (e.g. NEB61, REB89).

10. He even speaks of 'abusive language' in this regard (2007:130 footnote 36$)$, but explains that the 'transforming power of the gospel to overcome ethnic distinctions is dulled when the abusive language is domesticated.

11.LaGrand (1993:44-54) also argues against the use of 'Gentiles' . (He specifically has the NRSV89 in view.) His main objection is that it is an esoteric term fabricated by theologians.

\section{See footnote 18}

13.The Gute Nachricht Bibel (1997) consistently avoids using 'Heiden'. It oscillates between 'the other nations' ('die andern Völker'), 'the non-Jewish nations' or 'the nations'. Also the Nieuwe Nederlandse Bijbelvertaling (2004) moves in this direction, although it still retains 'heidene' in certain instances.

14.Cf. Galatians 3:8. This may also be the case in Romans 15:11-12, but the contex makes it more likely that, as in 15:9-10, $\epsilon^{\prime} \theta \nu \eta$ has only the non-Jewish nations in view.

15.But see the previous footnote for Romans 15:11-12 
issues make faith and moral evaluations unavoidable. It will be unfair, even futile, to the nature of the biblical texts to try and excise negative evaluations from them. ${ }^{16}$ Thirdly, the literary type of the specific text, e.g. its rhetorical nature, should be taken into account. And finally, we should consider the "̈ $\theta \nu \eta$ texts in Romans within the broader contexts of the Pauline homologoumena.

As point of departure we may accept that, in line with Paul's Jewish legacy, the two main diagnostic constituents of $\epsilon^{\prime \prime} \theta \nu \eta$ would be, first, that the bearers of this designation were nonJews (ethnical distinction) and, secondly, that they did not believe in the God of Israel (religious distinction). ${ }^{17}$ In the latter sense, they could be regarded as 'non-believers' or 'pagans'. In the vast majority of the 49 undisputed Pauline occurrences of $e^{\prime \prime} \theta v \eta$, these two meanings go hand in hand and it is in fact impossible to separate them. In these instances, 'Gentiles' or 'Gentile nations' (where applicable), would still be the preferable translation, since this English term covers both features. ${ }^{18}$ This will naturally also be valid for the majority of instances in Romans. ${ }^{19}$

There are, however, five instances where the religious (moral) constituent is primarily, if not exclusively, in focus. These are Romans 2:14; 1 Corinthians 5:1; 12:2; Galatians 2:15 and 1 Thessalonians 4:5. In all of these, the moral behaviour of people outside the Judaeo-Christian sphere is evaluated. In four cases, the result is negative: they are prone to lustful passions $(1 \mathrm{Th}$ 4:5), immoral (1 Cor 5:1), allow themselves to be led astray to dumb idols (1 Cor 12:1), sinners (Gal 2:15). Significantly, there is also a positive evaluation: in Romans 2:14 Paul mentions $\epsilon^{\prime \prime} \theta \nu \eta$ who 'do by nature what the law requires'. In all of these instances it seems appropriate to use 'heathens' or 'pagans'.

\section{$\Lambda$ ОГIZOMAI}

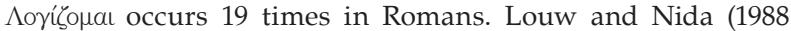
[2]:153) list the following meanings, (1) 'reason about', (2) 'keep mental record', (3) 'hold a view' and (4) 'charge to account'. ${ }^{20}$

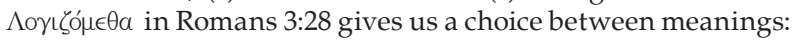
(1) 'reason about' and (3) 'to hold a view'. The Revised English Bible (1989) opted for (1) and translates $\lambda$ 잉ํ $\in \Theta a$ by 'our argument is'. In this case, Paul would be referring to a reasoning process, as in 1 Corinthians 13:11 ('When I was a child ... I reasoned like a child'). The New International Version (1984), on the other hand, prefers (3) when it translates 'For we maintain ${ }^{21}$ that a man is justified by faith'. Both these meanings would fit the context, but since we deal with a strong conviction, meaning (3) is preferable.

16.Cf. the satire against the idols in Isaiah 44; Jesus' castigation of the religious leaders in Matthew 23; the vilification of opponents in the New Testament letters. On the other hand, Paul's use of " $\theta \nu \eta \eta$ is characterized by a strong 'matter-offactness'. Of his multiple references to the " $\theta \theta \nu \eta$, only a very few may be regarded as derogatory, (see below), and none of these occur in Romans.

17.See in this regard Hulst (1976:col. 321-324). For the New Testament, cf. Walter 1980

18.Both meanings are attested in The Oxford English Dictionary Vol. VI, s.v. (see Simpson \& Weiler [eds.] 1989), the Shorter Oxford English Dictionary Vol. s.v. (see Trumble \& Stevenson [eds.] 2002) and Webster's Third International Dictionary of the English Language Unabridged Vol I s.v. (see Gove [ed. in chief] 1961).

19.I therefore disagree with Jewett that, in Romans, Paul uses $\ddot{\epsilon} \theta \nu \eta$ in a derogatory manner. The only four instances in his undisputed letters which may be regarded manner. The only four instances in his undisputed letters which may be regarded
as derogatory are 1 Corinthians $5: 1 ; 12: 2$; Galatians $2: 15$ and 1 Thessalonians $4: 5$ as derogatory are 1 Corinthians $5: 1 ; 12: 2$; Galatians $2: 15$ and 1 Thessalonians $4: 5$
(see below). Since the ethnic element is in focus in Romans $11: 13$ and Galatians (see below). Since the ethnic element is in focus in Romans 11:13 and Galatians
2:12 (14?), 'non-Jews would be preferable. In Romans 10:19 "ै $\theta v \in($ (bis) simply designates 'nation'.

20.We should keep in mind that these four variants indicate different semantic domains, but each of them signifies only the kernel of a wider group of closely related semantic possibilities.

21.The Cambridge Advanced Learner's Dictionary (ad vocem) (see Walter [senior commissioning ed.] 2008) defines 'to maintain', when used in this sense, as 'to express firmly your belief that something is true'.
Since Louw and Nida offer only Romans 4:4 as example for option (4) ('charge to account'), this meaning may seem to be applicable only to material accounts (credits and debits).

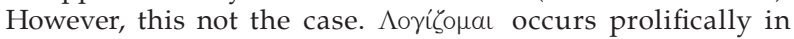
Romans 4 and in twelve of the thirteen instances it is used figuratively in the sense that immaterial things such as faith, trust and sinning affect one's 'account' before God. The New International Version (1984) and The New English Translation (1996) reflect this appropriately when they consistently translate

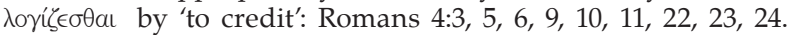
Romans 4:5, for instance, reads: '[h]owever, to the man who does not work but trusts God who justifies the wicked, his faith is credited as righteousness' (NIV84). The only exception is

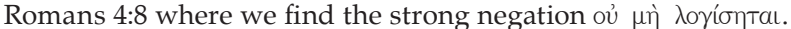
This verse is translated: '[b]lessed is the man whose sin the Lord will never count against him' (NIV84).

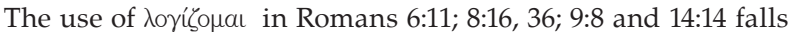
consistently within Louw and Nida's broad semantic domain (3): 'hold a view'. When looking for a translation for $\lambda$ oyí̌ $\epsilon \sigma \theta \in$ in Romans 6:11, verbs such as 'consider' ${ }^{22}$ or 'reckon' first spring to mind. However, we should ask whether renderings such as these sufficiently reflect the assurance and urgency inherent in Paul's injunction. He develops his argument from 6:2b, and particularly from $6: 3$ onwards, to prove that it is absolutely unthinkable that Christians should continue in a life of sin (cf.

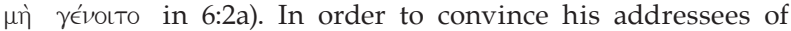
the 'impossibility' of such a life in sin, he applies one of the most powerful weapons in his arsenal, namely their baptism. In 6:11, he draws an emphatic conclusion which leaves no room for uncertainty. Therefore it would be better to render

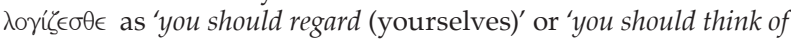
(yourselves)' or 'you should realise (that you are)'. The Good News Translation (1992), for example, says: 'In the same way you are to think of yourselves as dead, so far as sin is concerned, but living in fellowship with God through Christ Jesus.' (my emphasis)

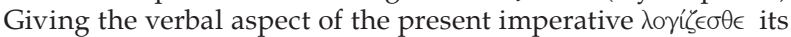
full force, we could even say: 'Therefore you should constantly think of yourselves as dead to sin but alive to God in/through Christ Jesus. ${ }^{23}$

Five recent translations of Romans 8:16 read as follows (italics added):

NIV84: 'I consider that our present sufferings are not worth comparing with the glory that will be revealed in us.

REB89: 'For I reckon that the sufferings we now endure bear no comparison with the glory, as yet unrevealed, which is in store for us.'

NRSV89: I I consider that the sufferings of this present time are not worth comparing with the glory about to be revealed to us.'

GNB97: 'Ich bin überzeugt: Was wir in der gegenwärtigen Zeit noch leiden müssen, fällt überhaupt nicht ins Gewicht im Vergleich mit der Herrlichkeit, die Gott uns zugedacht hat und die er in der Zukunft offenbar machen wird.'

NBV04: Ik ben ervan overtuigd dat het lijden van deze tijd in geen verhouding staat tot de luister die ons in de toekomst zal worden geopenbaard.'

The first three translations, agreeing with our traditional

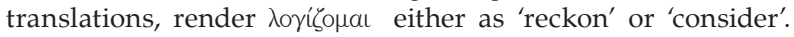
However, both these English verbs contain some element of uncertainty. Such tentativeness is ill at place, since Paul is expressing his joyful expectation of the coming glory. Realising this, Newman and Nida correctly chose for 'I am assured' or

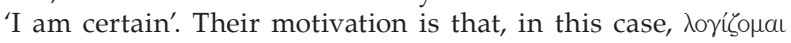
'expresses strong assurance and not doubt' and they continue

22.Cf. RSV52; NRS89; NET96; NLT96.

23.For possible translations of the 'in Christ' formula, see Du Toit 2010a. 
to say that 'a translation such as "I think" may imply less than what Paul intends' (1973:157). The context undoubtedly requires a translation such as 'I am certain' or 'I am convinced'. This is in agreement with the readings of the Gute Nachricht Bibel (1997) and the Nieuwe Bijbelvertaling (2004) given above. ${ }^{24}$

In the foregoing, I addressed some translation problems which repeatedly occur in Romans. We shall now turn to some ad hoc ones.

\section{PAUL'S ADMONITION REGARDING THE CHARISMATA IN ROMANS 12:6-8}

In Romans 12:6-8, Paul admonishes his addressees on how they should exercise their spiritual gifts. The New International Version (1984) is representative of most translations (my numbering):

We have different gifts, according to the grace given us.

1. If a man's gift is prophesying, let him use it in proportion to his faith.

2. If it is serving, let him serve.

3. If it is teaching, let him teach.

4. If it is encouraging, let him encourage.

5. If it is contributing to the needs of others, let him give generously.

6. If it is leadership, let him govern diligently.

7. If it is showing mercy, let him do it cheerfully.

As translated here, the admonition on how to practise the second to the fourth gifts, does not make much sense. The intent of the duplication is not clear.

We may come closer to a solution when we look at the development of Paul's argument. His main concern is that those who are inclined to think too highly of themselves and their gifts, not only abuse the latter, but also disrupt the unity and harmony of the body of believers. He prepares the way in 12:3 by first characterising his own position as a grace that has been given to him (and therefore certainly not an achievement of his own); thereupon he warns against self-conceit (cf. $\mu$ i

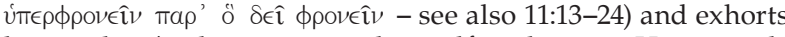
his readers/audience to a sober self-evaluation. He reminds them that everyone's 'measure of faith' is God-given, thus subtly reiterating the grace motif and indicating that there is a measured differentiation within which everyone should find his/her own place. Finally, after stressing the bond between and mutual responsibility of the various members towards one another and to the one body to which they belong (12:4-5), he mentions the gifts, once again stressing the grace motif (12:6). He is bent on creating an attitude of humility and level-headedness. It would be entirely out of step to overrate a specific gift and use it as an instrument of self-elevation. Each believer, in practising his/her individual gift, should concentrate on what is intrinsic to the correct use of that gift. In instances 1 and 5-7 the apostle manages to identify such a qualification. In 2-4 he fails to do it but intentionally repeats it to emphasise its specific character. Within the broader context, the reason for this seems to be that believers should concentrate on applying their specific gifts to the best of their abilities without any ulterior motives. This understanding is confirmed by the way the gift of sharing (5) is qualified.

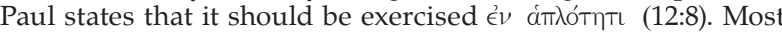
translations render this phrase by the adverb 'generously'.

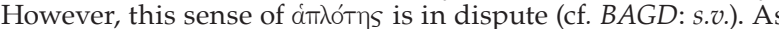
in 2 Corinthians 1:12 and 11:3 (cf. Eph 6:5 and $\mathrm{Col}$ 3:22), it would rather mean 'with sincerity/with integrity', that is without ulterior motives such as gaining personal honour or material advantages. ${ }^{25}$ This qualification was important, since we know that in Paul's world charitable actions such as benefaction were to a strong degree governed by the do ut des principle.

\section{In Romans 8:36; 9:8 and 14:14 'to consider' or 'to reckon' would be preferable.}

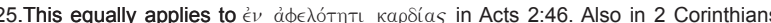
8.22 and $9: 11,13$ it is uncertain whether 'generosity' is the best translation. See Martin $(1986: 253,292)$.
I would therefore suggest that Paul's admonition regarding gifts $2-4$ could be rendered as follows:

- If it is serving, let us concentrate on it/let us fully apply ourselves to it. ${ }^{26}$

- If it is teaching, let us concentrate on that/let us fully apply ourselves to it.

- If it is encouraging, let us concentrate on that/let us fully apply ourselves to it.

\section{ROMANS 14:4}

To illustrate the problems of commentators with Romans 14:4, we may compare the translations of Barrett (1957:255), Cranfield (1979:698) and Jewett (2007:829). The bone of contention is the identity of the lord/Lord referred to (italics added):

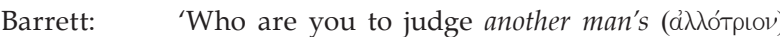

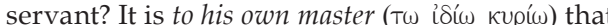
he stands or falls; yes, and he shall stand, for his master (o kúp Los) is able to make him stand.

Cranfield: 'Who art thou that passest judgement on Another's house-slave? It is his own Lord whose concern it is whether he stands or falls; and he shall stand for his Lord has the power to make him stand.'

Jewett: 'Who are you to be judging another's house slave? It is in relation to his own Lord that he stands or falls. He will be made to stand because the Lord has the power to enable him to stand.'

We could borrow Black's distinction between the 'tenor' and 'vehicle' in metaphorical language to outline the problem. 'Tenor' is the real life item (or person), represented by certain lexical items, to which (whom) the metaphor is applied. The 'vehicle' is the linguistic means by which this application is generated..$^{27}$ In the case of Romans $14: 4$, we can say that the tenor part consists of Jesus the Lord (кúpıos) and the 'strong' and the 'weak' Roman Christians. The vehicle part consists of two house-slaves (oikeTaí ${ }^{28}$ ), belonging to two different but typical first-century households. The scenario created in the vehicle part is the impropriety of the slave of the one household to criticise the house-slave of the other household. The only person who has the right to judge about such a slave's conduct is his own master. In order to foreground this point, the reference to the master is placed at the beginning of $14: 4 \mathrm{~b}$. The real life application of the metaphor would then be that it is totally out of order for one believer to criticise the conduct of another, since that right belongs exclusively to Jesus the Lord. The congruity between the vehicle and the tenor is due to the fact that the master-slave relation is in a sense analogous to the relationship between Jesus the Lord and the believers. But this very same congruity also causes the problem, since the term kúpios can signify both the earthly slave-owner and Jesus. The question is: where does the vehicle part disappear from the surface level and the tenor part begin (that is, appears on the surface level)? Barrett, Cranfield and Jewett each answer this question differently. For Barrett, the whole of 14:4 constitutes the vehicle and the tenor is merely implied, although the message is clear. For Cranfield, the tenor surfaces almost immediately, as indicated by the fact that he already capitalises 'another' and then proceeds to relate all the kúpıs references to Jesus Christ. Jewett, in turn, prefers an in-between position.

In my opinion, it makes the best sense to accept that the vehicle part consists of two propositions, the first one, in 14:4a, indicating that it would be presumptuous of one house-slave to judge the house-slave of another master; the second one, in $14: 4 \mathrm{~b}$, that only the master of that slave is entitled to make a judgement. The vehicle part is not completed until Paul has made this second proposition. This would mean that the English equivalent for kúptos in 14:4b should remain uncapitalised. In

26. The 'we-language' continues the tenor of Paul's presentation in 12:4-6.

27.Cf. Van der Watt (2009:309).

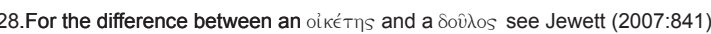


14:4c the situation is different. The assurance that the slave 'shall stand for his kúplos is able to make him stand', refers more readily to Jesus than to an ordinary slave-owner. The tenor has appeared on the surface. The translation equivalent for кúpıs in 14:4c should therefore be capitalised.

The remaining issue is the meaning of the 'stand - fall' antithesis in $14: 4 \mathrm{~b}$ and c. If our conclusion is correct that $14: 4 \mathrm{~b}$ still belongs to the vehicle, we need not look for heavy eschatological

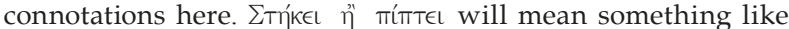
'to prevail/succeed' or 'to fail' (cf. GNT92). In 14c we could use 'prevail/succeed' once more, but now it carries eschatological connotations. I would therefore submit that we should translate 14:4 as follows: 'Who are you to be judging someone else's house-slave? It is for his owner to decide whether he prevails or fails; but he will prevail, for his Lord has the power to let him prevail.'

\section{TA ПIPO $\Sigma$ TON $\Theta E O N$ IN ROMANS 15:17}

Quite literally translated, Romans 15:17 reads: 'I therefore have this boasting in Christ Jesus with respect to the things before God (Tà mpòs tòv $\theta \in o ́ v)$. This rather unusual phrase, which also appears in Hebrews 2:17 and 5:1, causes considerable problems, as becomes clear when one compares commentaries and translations. German works prefer to render it as 'vor Gott' (e.g. Schlier, 1977:427; Michel 1978:454; Wilckens, 1982 III:116; Stuhlmacher, 1989:208; Lut84), while English works prefer 'my work for God' or 'my service to God' (e.g. RSV52; NIV84; NRSV89; REB89; GNT92).

A survey of the use of Tà mpòs Toús $\theta \in o u ́ s$ in a large variety of Greeks texts, including the papyri and inscriptions, indicates that it was used widely in a cultic sense, its immediate context specifying its meaning more exactly (see Du Toit 2010b). In the three New Testament texts it naturally appears in monotheistic adaptation. In Hebrews 2:17 and 5:1 its cultic connotations are undeniable. But this is also the case in Romans 15:17 where it occurs within a context where Paul describes his apostolic mission in priestly terms (cf. 15:16). I would therefore suggest the following translation: 'I am therefore glorying (or rejoicing), through Christ Jesus, that I may bring this offering before God'. The offering which he presents to God, consists of the Gentiles who accepted his preaching of the gospel. ${ }^{29}$

\section{REFERENCES}

Bible translations and their abbreviations:

GNT92: Good News Translation 1992

GNB97: Die Gute Nachricht Bibel 1997.

LUT84: Die Bibel (Luther revised) 1984.

NAB86: The New American Bible 1986.

NBV04: De Nieuwe Bijbelvertaling 2004.

NET96: The New English Translation 1996

NIB61: $\quad$ The New English Bible 1961.

NIV84: The New International Version 1984.

NLT96: The New Living Translation 1996.

NRS89: The New Revised Standard Version 1989.

REB89: $\quad$ The Revised English Bible 1989.

RSV52: $\quad$ The Revised Standard Version 1952.

Barrett, C.K., 1962, A Commentary on the Epistle to the Romans, rev. edn., Black, London.

Bauer, W., Arndt, F.W., Gingrich, F.W. \& Danker, F.W., 2000, A Greek-English Lexikon of the New Testament and other Early Christian Literature, 3rd. edn., University of Chicago Press, Chicago (BAGD).

Bosman, P., 2003, Conscience in Philo and Paul. A Conceptual History of the Synoida Word Group, (WUNT 2. Reihe 166.), Mohr Siebeck, Tübingen.

Cranfield, C.E.B., 1977, The Epistle to the Romans, 2 vols, Clark, Edinburgh.
Dabelstein, R., 1981, Die Beurteilung der 'Heiden' bei Paulus, [The Assessment of the 'heathen'in Paul] (BET 14.), Peter Lang, Frankfurt a. M.-Bern-Cirencester.

Du Toit, A.B., 2007, Focusing on Paul. Persuasion and Theological Design in Romans and Galatians, (WUNT 151.), De Gruyter, Berlin-New York.

Du Toit, A.B., (ed.), 2009, Focusing on the Message: New Testament Hermeneutics, Exegesis and Methods, Protea, Pretoria.

Du Toit, A.B., [2010a], 'Translating Romans: Some persistent headaches', forthcoming in In die Skriflig 44.

Du Toit, A.B., [2010b], 'Tà mpòs tòv $\theta$ eóv in Romans and Hebrews: Towards understanding an enigmatic phrase', ZNW 101, 241-251.

Du Toit, H., 2009, 'Contributions from Modern Linguistics to New Testament Exegesis', in A.B. du Toit (ed.), Focusing on the Message: New Testament Hermeneutics, Exegesis and Methods, pp. 267-304, Protea, Pretoria.

Gove, P.B. (ed. in chief), 1961, Webster's Third New International Dictionary of the English Language Unabridged, G. Bell \& Sons, London, G. \& C. Merrian, Springfield.

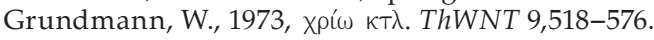

Hulst, A.R., 1976, 'am/gōj Volk, THAT 2, 290-235.

Jewett, R., 2007, Romans: A Commentary, (Hermeneia), Fortress, Minneapolis.

Kümmel, W.G., 1968, Kirchenbegriff und Geschichtsbewusstsein in der Urgemeinde und bei Jesus [Concept and awareness of history in the early church and Jesus]. 2. Aufl., Vandenhoeck \& Ruprecht, Göttingen.

LaGrand, J., 1993, 'Gentiles' in the New Revised Standard Version', BR 38:44-54.

Liddell, H.G., Scott, R. \&. Jones, H.S., 1985, A Greek-English Lexicon. Repr, Clarendon Press, Oxford.

Louw, J.P. \& Nida, E.A., 1988, Greek-English Lexicon of the New Testament based on Semantic Domains. 2 vols, United Bible Societies, New York.

Martin, R.P., 1986, 2 Corinthians, (WBC 40), Word Book Publisher, Waco, Texas.

Michel, O., 1978, Der Brief an die Römer, (KEK IV), 14th edn., Vandenhoeck \& Ruprecht, Göttingen.

Newman, B.M. \& Nida, E.A. 1973, A Translator's Handbook on Paul's Letter to the Romans. United Bible Societies, LondonNew York.

Roloff, J., 1993, Die Kirche im Neuen Testament [The church in the New Testament], (Grundrisse zum Neuen Testament. NTD Ergänzungsreihe 10), Vandenhoeck \& Ruprecht, Göttingen.

Schenk, W., 1995, 'Die ältesten Selbstverständnisse christlicher Gruppen im ersten Jahrhundert', ANRW II 26.2, 13571467.

Schlier, H., 1977, Der Römerbrief (HThK VI), Herder, Freiburg.

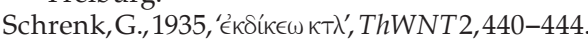

Scott, J.M., 1995, Paul and the Nations: The Old Testament and Jewish Background of Paul's Mission to the Nations with Special Reference to the Destination of Galatians, (WUNT 84), Mohr Siebeck, Tübingen.

Simpson, J.A. \& Weiner, E.S.C., (eds.), 1989. The Oxford English Dictionary, 2nd. edn., Clarendon Press, Oxford.

Stuhlmacher, P., 1989, Der Brief an die Römer, (NTD 6), Vandenhoeck \& Ruprecht, Göttingen.

Trumble, W.R. \& Stevenson, A. (eds.), 2002, Shorter Oxford English Dictionary, 5th edn., Oxford University Press, Oxford.

Van der Watt, J. 2009, 'Reading New Testament Imagery', in A.B. du Toit (ed.), Focusing on the Message: New Testament Hermeneutics, Exegesis and Methods, pp. 305-340, Protea, Pretoria.

Walter, E. (senior commissioning ed.), 2008, Cambridge Advanced Learner's Dictionary, 3rd edn., Cambridge University Press, Cambridge, New York.

Walter, N., 1980, 'єै $€$ Vvos', EWNT 1, 924-929.

Wilckens, U., 1982, Der Brief an die Römer (Röm 12-16), (EKK V1/3), Benziger \& Neukirchen, Zürich. 